\title{
Pengaruh Massa Adsorben, Lama Kontak Dan Aktivasi Adsorben Menggunakan HCI Terhadap Efektivitas Penurunan Logam Berat (Fe)Dengan Menggunakan Abu Layang Sebagai Adsorben
}

\author{
Candra Irawan- ${ }^{1}$, Basri Dahlan- ${ }^{2}$, Nawang Retno- ${ }^{2}$ \\ Politeknik Negeri Balikpapan, Jl. Soekarno Hatta Km. 8 Balikpapan 76126 \\ email : candraarema1977@gmail.com
}

\begin{abstract}
This research has investigated adsorption of Fe with using fly ash adsorbent. Phases of adsorption of $\mathrm{Fe}$ is activated with HCI after that the fly ash were characterized by using XRF and SEM. Determination of optimum conditions on the adsorption of Fe with adsorbent mass variations, variations in contact time. Resulth show that the adsorption of Fe in optimum condition occurs in adsorbent mass of $2.5 \mathrm{~g}$, for 60 minutes and the results also able to adsorp up to 96,34\% Fe.
\end{abstract}

Key words: adsorption, fly ash

\begin{abstract}
Abstrak
Telah dilakukan penelitian adsorpsi logam Fe dengan menggunakan adsorben abu layang Batubara. Tahapan adsorpsi logam Fe yakni mengaktivasi abu layang batubara dengan HCI setelah itu abu layang dikarakterisasi dengan menggunakan XRF dan SEM. Penentuan kondisi umum pada adsorpsi logam Fe dilakukan dengan variasi massa adsorben,variasi lama kontak, dan percobaan apa sampel air. Hasil penelitian menunjukkan bahwa adsorpsi logam Fe pada kondisi optimum terjadi pada massa adsorben 2,5 g, lama kontak selama 60 menit dan hasil penelitian ini juga mampu mengadsorpsi logam Fe hingga $96 \%$.
\end{abstract}

Kata Kunci: adsorpsi, abu layang

\section{Pendahuluan}

Abu layang (fly ash) batubara dihasilkan pada pembakaran batubara dalam PLTU yang berupa partikel abu yang terbawa oleh gas buang sedangkan abu yang tertinggal dan dikeluarkan dari bawah tungku disebut abu dasar (bottom ash). Di Indonesia produksi limbah fly ash batubara dan abu dasar dari tahun ke tahun meningkat. Pada tahun 2009 produksi abu layang sudah mencapai 2,78 juta ton (Aziz., 2006)

Abu layang (Fly ash) batubara tersebut umumnya dibuang di landfill atau ditumpuk begitu saja di dalam area industri. Penanganan fly ash batubara masih terbatas pada penimbunan di lahan kosong. Hal ini berpotensi berbahaya bagi lingkungan dan masyarakat sekitar jika terbawa ke perairan. Bila ini dibiarkan terus menerus maka fly ash tidak mempunyai nilai ekonomi dan justru akan menimbulkan masalah bagi lingkungan sekitarnya seperti warga masyarakat mengalami infeksi pernafasan, perkakas dan jemuran pakaian masyarakat disekitar PLTU kotor terkena abu.

Akan tetapi selain terdapat dampak negatif yang ditimbulkan, abu layang (fly ash) juga mempunyai situs positifnya yakni kompositus kimianya sebagian besar tersusun atas oksida logam terutama $\mathrm{SiO}_{2}$ dan $\mathrm{Al}_{2} \mathrm{O}_{3}$ yang mempunyai situs aktif sehingga dimungkinkan dapat digunakan sebagai adsorben logam berat (Mattigold et al.,1990). 
Penelitian ini juga bertujuan sejauh mana kapasitas adsorpsi abu layang terhadap logam Fe yang terdapat pada air tanah di Balikpapan karena kualitas air tanah atau air sumur bor di Balikpapan masih di bawah standar air bersih dan tidak layak konsumsi, karena kandungan Fe sangat tinggi, selain itu air berwarna kekuningan dan berbau. Hal ini dapat di amati secara kasat mata dimana terbentuknya lumut-lumut kuning pada bak mandi, serta adanya endapan pada dasar bak mandi merupakan indikasi bahwa air memiliki tingkat kekeruhan yang tinggi. Keadaan ini terjadi karena air sumur yang di kelola oleh masyarakat tidak di olah terlebih dahulu. Meski air sumur sebagian tidak layak dikonsumsi, masyarakat tetap memanfaatkan air sumur ini untuk mandi, mencuci piring, mencuci pakaian, dan kebutuhan sehari-hari lainnya (Danielyn., 2009).

Pada Kelurahan Lamaru pada RT 20 di Balikpapan ini terdiri dari $152 \mathrm{KK}$ tetapi yang bisa merasakan air bersih hanya $28 \mathrm{KK}$ saja sehingga sisanya masih mengandalkan air hujan dan air tanah yang tidak memenuhi standar air bersih sehingga banyak penduduk yang terpaksa memanfaatkan air yang kurang bagus kualitasnya. Tentu saja hal ini akan berakibat kurang baik bagi kesehatan masyarakat pada jangka pendek seperti iritasi pada kulit, dan gatalgatal. Tingginya konsentrasi logam inilah yang menyebabkan air tersebut berwarna kuning dan berbau yang menunjukkan adanya kandungan besi (Fe) yang melebihi kadar maksimal dalam air yaitu lebih dari $1,0 \mathrm{mg} / \mathrm{l}$ (PerMenKes RI No 416/Per/IX/1990).

Beberapa penelitian guna mengurangi kadar logam pada limbah salah satunya melalui proses adsorpsi. Proses adsorpsi merupakan salah satu alternatif pengolahan yang sangat diminati karena selain dapat menyisihkan parameter pencemar, proses adsorpsi tidak rumit dalam pengerjaan dan ekonomis (Chien Jung Lien, 1999). Bahan yang pernah dimanfaatkan sebagai adsorben oleh masyarakat Lamaru Balikpapan hanya mengandalkan pasir dan kerikil kemudian ditempatkan di drum tetapi air didapatkan masih keruh dan sedikit berbau. Bahan alternatif yang bisa dimanfaatkan sebagai adsorben dalam proses adsorpsipun dapat berasal dari berbagai material termasuk dari sisa hasil pembakaran batubara yang lebih dikenal dengan abu layang ( fly ash). Keuntungan adsorben berbahan baku abu layang ( fly ash) adalah biayanya yang murah. Selain itu adsorben ini dapat digunakan baik untuk pengolahan limbah cair dan dapat digunakan dalam penyisihan logam berat dan limbah zat warna (Papandreou, 2007)

Fokus penelitian ini yaitu mempelajari pengaruh aktivasi dengan $\mathrm{HCl}$ dengan karakterisasi dengan XRF dan SEM. Kemudian juga mempelajari pengaruh massa adsorben dan lama kontak terhadap proses adsorpsi logam $\mathrm{Fe}$ menggunakan adsorben dari abu layang sebagai dengan metode batch. Untuk mengetahui pengaruh massa adsorben dan lama kontak, pada penelitian ini akan digunakan variasi massa adsorben 1, 1,5, 2, 2,5, 3, 3,5 dan 4, sedangkan variasi lama kontak yaitu 15, 30, 45, 60, 75, $90 \mathrm{t}$ dan percobaan sampel asli.

\section{Metode Penelitian}

\section{Alat}

Alat yang digunakan adalah oven merk Fisher Scientific Isotemp Oven 
Model 655F, ayakan (150 dan 180 mesh) , timbangan analitik merk mettle AE.50, seperangkat alat gelas, shaker rotator type H-SR-200, pH meter (Onilab, Schott Gerate pHMeter CG 820), pengaduk magnetik (Heidolp MR 1000), Spektrofotometri Infra Merah (FTIR-8000 PC Shimadzu) , Scanning Electron Microscope (SEM) JEOL JSM6390A, Spektrofotometer Shimadzu UV-160 A dan Spektrofotometer Serapan Atom (SSA).

\section{Tahap Penelitian}

\section{Preparasi Abu Layang Batubara}

Abu layang sebanyak $30 \mathrm{~g}$ dicuci dengan akuades, dikeringkan dalam oven pada temperature $110^{\circ} \mathrm{C}$ selama 3 jam dan ditempatkan didalam desikator. Abu layang yang kering tersebut ditimbang sampai diperoleh berat konstan kemudian diayak dengan ayakan berukuran 150 mesh, padatan yang lolos diayak lagi dengan ayakan berukuran 180 mesh. Padatan yang tertahan pada ayakan kedua digunakan untuk penelitian selanjutnya.

\section{Aktivasi Abu layang batubara}

Abu layang hasil preparasi ditimbang 10 gram dan dimasukkan kedalam gelas kimia dan ditambah $30 \mathrm{~mL}$ larutan $\mathrm{H}_{2} \mathrm{SO}_{4}$ dengan konsentrasi $4 \mathrm{M}, \quad 6 \mathrm{M}$ atau $8 \mathrm{M}$. Campuran direndam selama 24 jam setelah itu disaring dan dicuci dengan akuades sampai $\mathrm{pH}$ 7. Abu layang yang telah dicuci kemudian dikeringkan dalam oven pada temperature $110^{\circ} \mathrm{C}$ selama 3 jam.

\section{Karakterisasi fly ash}

Komposisi dari Abu layang batubara ditentukan dengan menggunakan $\mathrm{X}$ Ray fluorescence spectrometer, adanya gugus fungsi (situs aktif) pada adsorben abu layang ditentukan dengan menggunakan FTIR dan permukaan dari abu layang sebelum dan sesudah aktivasi diamati dengan menggunakan SEM.

\section{Penentuan Kondisi Optimum adsorpsi logam Fe}

Pengaruh massa adsorben abu layang batubara

Menyiapkan 5 larutan $\mathrm{FeCl}_{3}$ masingmasing sebanyak $100 \mathrm{ml}$ dengan konsentrasi optimum kemudian ditambahkan adsorben fly ash dengan variasi berat 0,$5 ; 1 ; 1,5 ; 2 ; 2,5$ gram kemudian diaduk dengan kecepatan $100 \mathrm{rpm}$ selama 30 menit. Selanjutnya larutan disaring dengan menggunakan kertas saring dan filtratnya diambil sebanyak $5 \mathrm{ml}$ dan diencerkan pada 100 ml akuades dan dianalisa dengan AAS dengan panjang gelombang 248,3 $\mathrm{nm}$. Setelah itu dibuat kurva antara $\% \mathrm{Fe}$ teradsorpsi dengan variasi berat adsorben, dari kurva tersebut akan didapatkan berat optimum.

\section{Pengaruh lama kontak terhadap} adsorpsi logam $\mathrm{Fe}$

Menyiapkan 5 larutan $\mathrm{FeCl}_{3}$ masingmasing sebanyak $100 \mathrm{ml}$ dengan konsentrasi optimum kemudian ditambahkan adsorben fly ash dengan berat optimum kemudian diaduk dengan kecepatan 100 rpm selama 15 , 30, 45, 60 dan 75 menit. Selanjutnya larutan disaring dengan menggunakan kertas saring dan filtratnya diambil sebanyak $5 \mathrm{ml}$ dan diencerkan pada $100 \mathrm{ml}$ akuades dan dianalisa dengan AAS dengan panjang gelombang $248,3 \mathrm{~nm}$. Setelah itu dibuat kurva antara \% Fe teradsorpsi dengan waktu pengocokan, dari kurva tersebut akan didapatkan waktu pengocokan optimum.

Percobaan dengan sampel asli 
Kondisi optimum yang sudah didapat selanjutnya dikondisikan terhadap sampel asli. $50 \mathrm{ml}$ sampel asli ditambahkan adsorben fly ash dengan berat optimum setelah itu diatur dengan $\mathrm{pH}$ optimum kemudian diaduk dengan kecepatan 100 rpm selama waktu optimum. Selanjutnya larutan disaring dengan menggunakan kertas saring dan filtratnya diambil sebanyak $5 \mathrm{ml}$ dianalisa dengan AAS dengan panjang gelombang $248,3 \mathrm{~nm}$.

\section{Aktivasi abu layang menggunakan HCl}

Dalam penelitian ini sebelum abu layang batubara digunakan dalam proses adsorpsi, abu layang batubara diaktivasi terlebih dahulu menggunakan asam klorida dengan variasi konsentrasi yaitu 4M, 6M dan $8 \mathrm{M}$.
Proses aktivasi secara kimia menggunakan $\mathrm{HCl}$ dimaksudkan untuk menghilangkan zat pengotor yang ada pada abu layang dengan ion $\mathrm{H}^{+}$. Hal ini disebabkan oleh semakin besarnya jumlah ion $\mathrm{H}^{+}$yang masuk ke struktur abu layang maka semakin besar pula jumlah zat pengotor dalam abu layang yang tergantikan dengan ion $\mathrm{H}^{+}$(H-Abu layang) sehingga abu layang mempunyai gugus aktif yang mudah melepaskan proton yaitu gugus asam Bronsted (Poerwadi, dkk, 1995). Peristiwa pergantian zat pengotor (X) yang ada pada abu layang dengan ion $\mathrm{H}^{+}$akibat dari aktivasi abu layang dengan $\mathrm{HCl}$ dapat menyebabkan gugus asam Bronsted (Gambar 5.1) (Nicolette R, 2005).

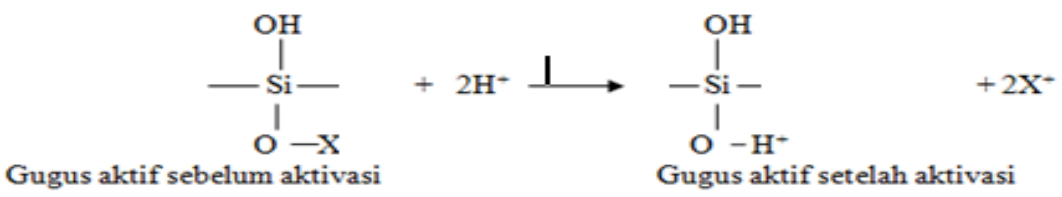

Gambar 1. Proses aktivasi asam pada abu layang

Untuk mengetahui unsur pada abu layang dengan menggunakan instrumen XRF. Hasil karakterisasi dengan XRF abu layang sebelum aktivasi dan setelah aktivasi dengan $\mathrm{HCl} 4 \mathrm{M}, 6 \mathrm{M}$ dan 8M ditunjukkan pada Tabel 5.1.

Tabel 1. Komposisi unsur abu layang hasil dari XRF

\begin{tabular}{|c|c|c|c|c|c|}
\hline \multirow{2}{*}{ No } & \multirow{2}{*}{ Unsur } & $\begin{array}{c}|c| \\
\text { belum } \\
\text { aktivasi }\end{array}$ & HCl 4M & HCl 6M & HCl 8M \\
\hline 1 & $\mathrm{Fe}$ & 42,4 & 33,8 & 38,5 & 8,3 \\
\hline 2 & $\mathrm{Ca}$ & 28,4 & 8,99 & 12,6 & 8,6 \\
\hline 3 & $\mathrm{Si}$ & 16,5 & 47,8 & 34,4 & 50,75 \\
\hline 4 & $\mathrm{Al}$ & 6,1 & 0,1 & 0,1 & 35,4 \\
\hline 5 & $\mathrm{~K}$ & 1,77 & 3,49 & 3,06 & 0 \\
\hline 6 & $\mathrm{Ti}$ & 1,2 & 1,8 & 1,63 & 1,1 \\
\hline
\end{tabular}


Berdasarkan data dala Tabel 4.1. kandungan $\mathrm{Fe}$ dalam abu layang sebelum diaktivasi masih tinggi yakni $42,4 \%$ sedangkan kandungan $\mathrm{Si}$ hanya $16,5 \%$. Setelah aktivasi $\mathrm{HCl}$ $4 \mathrm{M}$ dan $6 \mathrm{M}$ unsur Si mulai meningkat yakni 47,8 \% dan menurun lagi 34,4 $\%$ tetapi unsur $\mathrm{Fe}$ masih lebih tinggi $33,8 \%$ dan $38,5 \%$. Setelah aktivasi $\mathrm{HCl} 8 \mathrm{M}$ unsur Si meningkat 50,75\% sedangkan unsur Fe turun $8,3 \%$. Hal ini dikarenakan adanya pergantian ion $\mathrm{Fe}^{2+}$ dengan ion $\mathrm{H}^{+}$akibat aktivasi abu layang dengan $\mathrm{HCl}$ menurut reaksi seperti dalam Gambar 4.1.
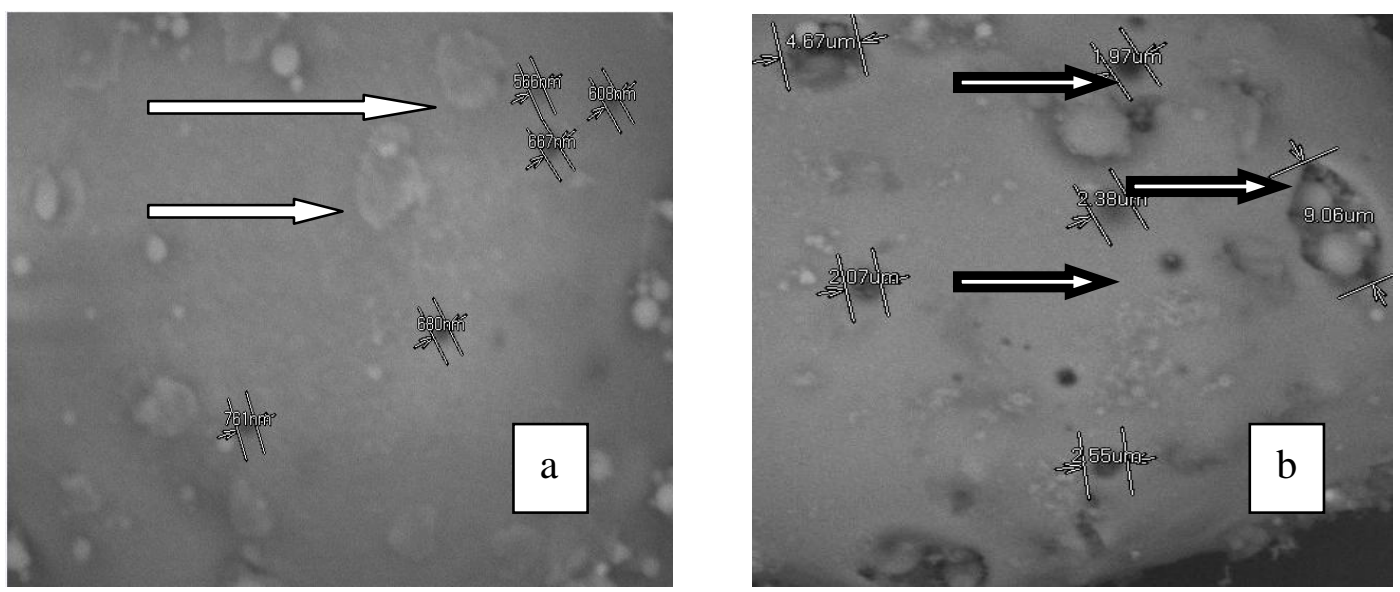

Gambar 2 Mikrograf SEM Abu layang (a) abu layang sebelum aktivasi (b) abu layang setelah aktivasi ( $\Rightarrow$ = zat pengotor yang menutupi permukaan adsorben) $(\vec{C}=$ menunjukkan pori $)$

Pada gambar 2 (a) terlihat sebagian pori abu layang masih tertutupi oleh zat pengotor sehingga jumlah porinya lebih sedikit dibandingkan jumlah pori setelah diaktivasi serta menunjukkan diameter pori abu layang sebelum aktivasi $(566 \mathrm{~nm} \quad-761 \mathrm{~nm})$ dibandingkan dengan diameter pori setelah diaktivasi dengan $\mathrm{HCl}(1,97$ $9,06 \mu \mathrm{m})$.

Pada Gambar 2 (b) terlihat permukaan abu layang setelah diaktivasi zat pengotor sudah tidak
Berdasarkan data dalam Gambar 4.2. abu layang sebelum morfologi permukaan dengan abu layang sesudah aktivasi $\mathrm{HCl}$. Menurut penelitian Dede ( 2010 ) bahwa abu layang yang teraktivasi dengan $\mathrm{HCl} 8 \mathrm{M}$ memiliki luas permukaan spesifik lebih besar daripada abu layang tanpa perlakuan aktivasi yaitu sebesar 16,1306 $\mathrm{m}^{2} / \mathrm{g}$ sedangkan abu layang tanpa aktivasi hanya $4,3461 \mathrm{~m}^{2} / \mathrm{g}$. aktivasi memiliki perbedaan 
100 rpm. Variasi massa adsorben yang digunakan adalah 1,$0 ; 1,5 ; 2,0$; 2,$5 ; 3,0 ; 3,5$ dan $4,0 \mathrm{~g}$.

Berdasarkan data dalam Gambar 4.3 dapat diketahui bahwa massa $\mathrm{Fe}$ teradsorpsi meningkat hingga penggunaan adsorben 2,5 g.
Sedangkan pada massa 2,5 - $4 \mathrm{~g}$ massa $\mathrm{Fe}$ teradsorpsi terjadi penurunan. Hasil penentuan pengaruh massa adsorben terhadap massa $\mathrm{Fe}$ teradsorpsi disajikan dalam Gambar 4.3 .

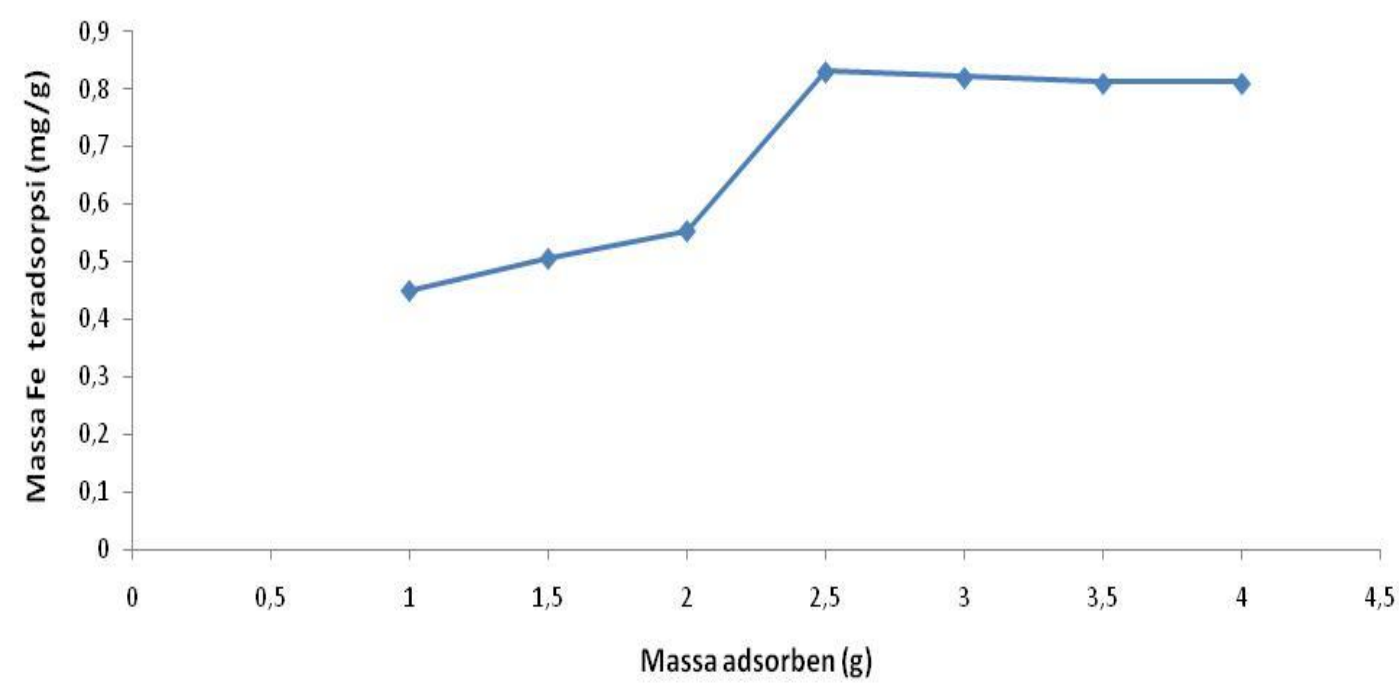

Gambar 3. Kurva pengaruh massa adsorben terhadap massa Fe teradsorpsi

Berdasarkan data dalam Gambar 3 dapat diketahui bahwa massa $\mathrm{Fe}$ teradsorpsi meningkat hingga penggunaan adsorben 2,5 g. Sedangkan pada massa 2,5 - $4 \mathrm{~g}$ massa $\mathrm{Fe}$ teradsorpsi terjadi penurunan. Penurunan massa $\mathrm{Fe}$ teradsorpsi disebabkan konsentrasi $\mathrm{Fe}$ yang terserap pada permukaan abu layang lebih besar dibandingkan konsentrasi $\mathrm{Fe}$ yang tersisa dalam larutan. Perbedaan konsentrasi tersebut menyebabkan ion $\mathrm{Fe}^{2+}$ yang sudah terikat pada abu layang akan terdesorpsi kembali ke dalam larutan. Kondisi optimum adsorpsi tercapai pada penggunaan massa adsorben 2,5 g dengan massa teradsorpsi yaitu 0,83 gram sehingga pada penelitian selanjutnya digunakan massa adsorben $2,5 \mathrm{~g}$.

\section{Pengaruh Waktu Kontak terhadap Adsorpsi ion $\mathrm{Fe}^{2+}$}

Penentuan pengaruh waktu kontak bertujuan untuk mengetahui berapa lama waktu yang dibutuhkan oleh adsorben untuk menyerap ion $\mathrm{Fe}^{2+}$ secara maksimum sampai tercapai keadaan setimbang. Kajian pengaruh lama kontak dilakukan dengan metode batch pada variasi waktu kontak 15, 30, 45, 60, 75, 90 dan 105 menit. Penelitian dilakukan pada konsentrasi adsorbat sebesar 20 ppm dengan massa adsorben 2,5 $\mathrm{g}$ dan kecepatan pengocokan $100 \mathrm{rpm}$.

Hubungan antara lama kontak dengan presentase adsorpsi $\mathrm{Fe}$ oleh abu layang batubara ditunjukkan pada Gambar 4. 


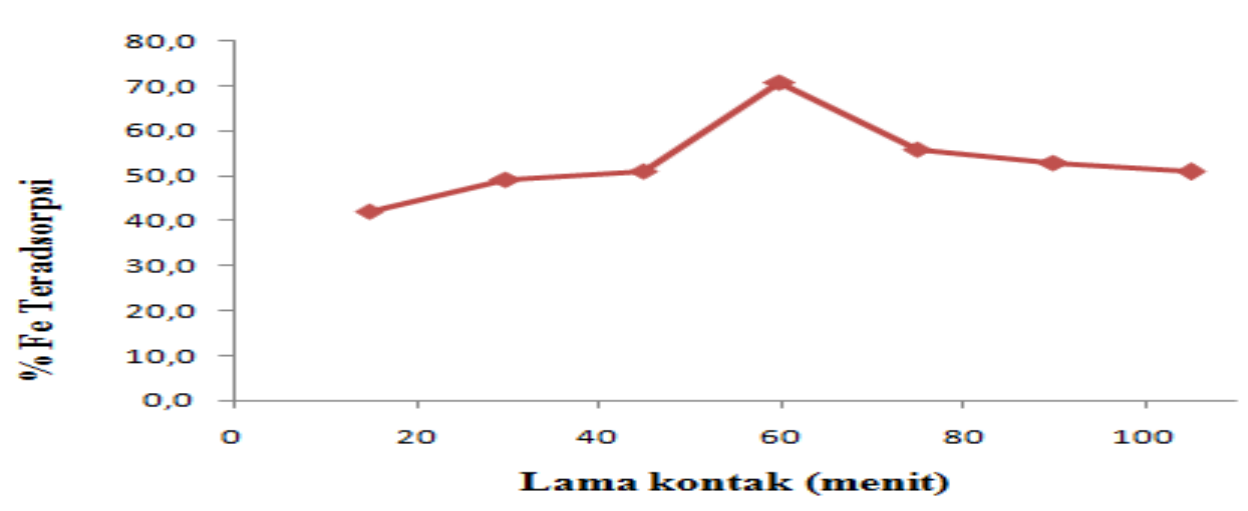

Gambar 4. Kurva pengaruh lama kontak terhadap \% adsorpsi

Berdasarkan data dalam Gambar 4 dapat dinyatakan waktu kontak 15 sampai 60 menit terjadi peningkatan persen adsorpsi yang cukup besar. Hal ini karena semakin lama waktu kontak mengakibatkan interaksi antara abu layang dengan ion $\mathrm{Fe}^{2+}$ semakin besar sehingga semakin banyak ion $\mathrm{Fe}^{2+}$ yang teradsorpsi oleh abu layang melalui reaksi pertukaran ion dengan ion $\mathrm{H}^{+}$dalam situs aktif abu layang.

Penurunan persentase ion $\mathrm{Fe}^{2+}$ teradsorpsi terjadi pada menit $60 \mathrm{ke}$ 105 hal ini karena semakin banyaknya ion $\mathrm{Fe}^{2+}$ yang terserap dalam abu layang maka akan saling berjejal dan luas permukaan adsorben semakin berkurang yang menyebabkan abu layang tidak mampu mengadsorpsi ion $\mathrm{Fe}^{2+}$ lagi sehingga ion $\mathrm{Fe}^{2+}$ yang sudah terikat pada abu layang akan terdesorpsi kembali ke dalam larutan. Waktu kontak optimum tercapai pada menit 60 dengan persen adsorpsi sebesar $70,3 \%$ sehingga penelitian selanjutnya digunakan waktu kontak 60 menit.

\section{Percobaan dengan air tanah}

Setelah diperoleh kondisi optimum adsorpsi ion $\mathrm{Fe}^{2+}$ pada sampel larutan sintesis (artifisial) selanjutnya dilakukan pada sampel air tanah. Sampel air tanah berasal dari Kelurahan Lamaru, Balikpapan dimana lokasi pengambilan sampel air tanah dapat dilihat pada Gambar 5

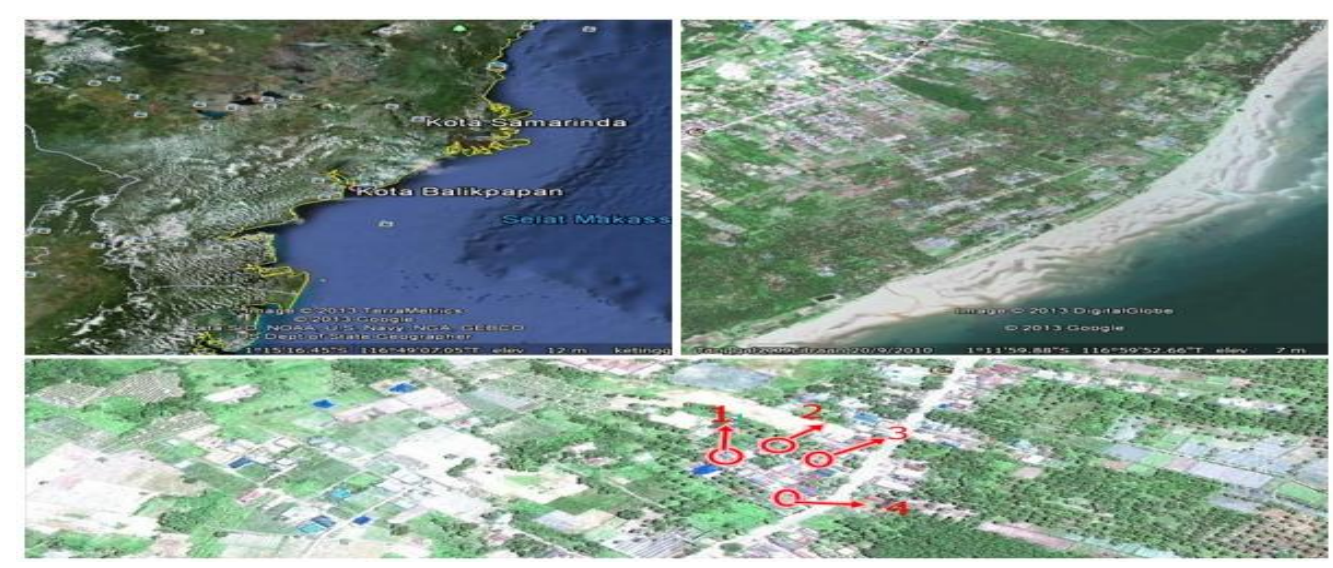

Gambar 5 Lokasi pengambilan air tanah 
Dari gambar 5. sampel air tanah diambil pada empat lokasi di Kelurahan Lamaru dimana sampel tersebut terlebih dahulu dilakukan analisis komposisi $\mathrm{Fe}$ yang terkandung didalamnya menggunakan AAS. Hasil analisa disajikan dalam Tabel 2

Tabel 2. Kandungan konsentrasi Fe sampel air tanah sebelum adsorpsi dan setelah adsorpsi di berbagai lokasi

\begin{tabular}{|c|c|c|c|c|}
\hline Lokasi & $\begin{array}{c}\text { Konsentrasi Fe } \\
(\mathrm{ppm}) \\
\text { sebelum } \\
\text { adsorpsi }\end{array}$ & $\begin{array}{c}\text { Konsentrasi } \\
\text { Fe (ppm) } \\
\text { setelah } \\
\text { adsorpsi }\end{array}$ & $\begin{array}{c}\% \\
\text { Adsorpsi }\end{array}$ & $\begin{array}{c}\text { Jumlah } \\
\text { massa Fe } \\
\text { teradsorpsi } \\
\text { (mg/g) }\end{array}$ \\
\hline $\begin{array}{l}\text { GL:1 }{ }^{\circ} 11^{\prime} 25.64 " S \\
\text { GB:116'59'37.49'T }\end{array}$ & 1,9718 & 0,1898 & 90,21 & 0,0350 \\
\hline $\begin{array}{l}\text { GL: }{ }^{\circ} 11^{\prime} 24.499^{\prime} \mathrm{S} \\
\text { GB: } 116^{\circ} 599^{\prime} 38.17^{\prime} \mathrm{T}\end{array}$ & 2,1237 & 0,2277 & 89,1 & 0,0372 \\
\hline $\begin{array}{l}\text { GL: } 1^{\circ} 11 ' 28.00 " S \\
\text { GB:11659'39.92"T }\end{array}$ & 2,5305 & 0.2729 & 89,03 & 0,0443 \\
\hline $\begin{array}{l}\text { GL: } 1^{\circ} 11^{\prime} 28.16^{\prime} \text { 'S } \\
\text { GB:116 } 59 \text { '38.46”T }\end{array}$ & 2,4045 & 0,2607 & 89,34 & 0,0421 \\
\hline
\end{tabular}

Data pada Tabel 4.2. menyatakan abu layang sebagai adsorben dalam kondisi optimum yaitu massa 2,5 gram, lama kontak 60 menit dengan kecepatan pengadukan $100 \mathrm{rpm}$ mampu mengadsorpsi ion $\mathrm{Fe}^{2+}$ pada sampel air tanah rata-rata sebesar $96,34 \%$.

Konsentrasi $\mathrm{Fe}^{2+}$ setelah diadsorpsi oleh adsorben abu layang diperoleh rata-rata $0,0396 \mathrm{ppm}$, hal ini telah sesuai dengan permenkes no.416 Th 1999 kadar Fe untuk baku air minum Golongan A di bawah 0,3 $\mathrm{mg} / \mathrm{L}$ dengan jumlah ion $\mathrm{Fe}^{2+}$ teradsorpsi rata-rata $0,0396 \mathrm{mg} / \mathrm{g}$. Artinya air sumur dapat digunakan sebagai bahan baku air minum setelah diproses menggunakan adsorben abu layang batu bara

\section{Kesimpulan}

Berdasarkan hasil penelitian dapat disimpulkan :

1. Aktivasi adsorben abu layang menggunakan $\mathrm{HCl}$ sangat berpengaruh terhadap karakteristik adsorben abu layang dengan meningkatnya persentase Si $50,75 \%$.

2. Kondisi optimum adsorpsi ion $\mathrm{Fe}^{2+}$ menggunakan adsorben abu layang diperoleh massa adsorben sebesar 2,5 gram, lama kontak pada waktu 60 menit,

3. Adsorpsi ion ion $\mathrm{Fe}^{2+}$ pada sampel air tanah rata-rata sebesar 89,34\% dengan kapasitas adsorpsi rata-rata $0,0396 \mathrm{mg} / \mathrm{g}$ menyebabkan air sumur dapat digunakan sebagai baku air minum. 


\section{Saran}

Perlu dilakukan penelitian lebih lanjut mengenai aktivasi dengan senyawa lain sehingga adsorben abu layang dapat mengadsorpsi logam berat dengan maksimal.

\section{Daftar Pustaka}

Alaerts, G. dan Sri Santika Sumestri, 1987, "Metode Penelitian Air". Surabaya: Usaha Nasional,

Balkus,K.J.J and Kieu, T.L, 1991

"The Preparation and

Characterization of an X-type Zeolite", J.Chem, Ed.,68 (10), 875 877

Basta, N.T., and Tabatabai, M.A. 1992, "Effect of Cropping Systems on Adsorption of Metal by Soil", edisi ke 2, J. Soil Sci, USA.

Castelan, G.W., 1983 "Physical Chemistry" London: Addison Wesley Publishing Company,.

Chien Jung, L., Juu-En, Ch. and Ming-Chun, L. 1999, “Application of fly ashes in the removal of metal ions from wastewater". Paper presented at the R'99 Congress (recovery, recycling, Re-integration). World Congress, Geneva,. Danielyn , 2009, “Analisa kualitas air bersih di Balikpapan,"

Balikpapan.

Darmono, 1995,'Logam Dalam Sistem Biologi Makhluk Hidup".UI Press:Jakarta.

Day, R. A. and A. L. Underwood. 2002,"Analisis Kimia Kuantitatif “ Edisi Keenam. Jakarta. Penerbit Erlangga. Hal 394, 396-404,.

Eaton, Andrew. Et.al. 2005, Standard Methods for Examination of Water and Wastewater. 21st Edition. Marryland - USA : American Public Health Association,. El-latif, M.M.A., Amal M. Ibrahim, M.F. El-Kady,2010, “Adsorption
Equilibrium, Kinetics and Thermodynamics of Methylene Blue from Aqueous Solutions Using Biopolymer Oak Sawdust Composite", Journal of American Science.

Flanigen,EM, Khatami, H., Szymanski, H.A. 1971, Infrared Structural Studies of Zeolite Framework, Molecular Sieves Zeolite-1, American Society Advanced in Chemistry Series No. 102, 201-227,.

Gatima, Chien Jung Lien. 2005,"Assessment of pulverized fly ash as an ameliorant of lead contaminated soils. Journal School of Biological Sciences," Plant and Soil Science, University of Aberden. Gretchen K. Hoffman, 2000, "Uses of fly ash from New Mexico Coals",New Mexico Geology,ISSN 0196-948X, Vol 22, No 2,

Hamdan, H, 1992, Introduction to Zeolites Syntesis, Characterization and Modification, First Edition, University teknologi Malaysia, Kuala Lumpur,

Jumaeri. 1995."Studi tentang Pemanfaatan Abu Layang Sebagai Adsorben Zat Warna dalam Larutan Air".Tesis, Universitas Gajah Mada:Yogyakarta.

Jumaeri, W.Astuti, 2007, "Preparasi dan karakterisasi zeolit dari abu layang batubara secara alkali hidrotermal," Jurnal Reaktor, Vol 11 No.1, Juni, hal:38-44

Karthikeyan, G., Anbalagan, K., Andal, N.M., 2004, Adsorption Dynamics and equilibrium Studies of $\mathrm{Zn}$ (II) onto Chitosan. Indian J. Chem . Sci.,116, 2, pp. 119-127

Khopkar, S. M. 1990, "Konsep Dasar Kimia Analitik".Jakarta. Penerbit Universitas Indonesia. Hal. $216-217$, 
Mattigold S.V., C.C. Ainsworth, L.E. Eary and D. Rai, 1990,“Geochemical factors controlling the mobilization of inorganic constituents from fossil fuel combustion residues":I. Review of the major elements. J. Environ. Qual.19:188-201.

Muchtar Aziz, 2006,"Karakterisasi Abu Terbang PLTU Suralaya dan Evaluasinya untuk Refraktori
Cor", Jurnal Teknologi Mineral dan Batubara, 36 (14), pp. 1-8.

Moret, A and J. Rubio, 2005, Sulphat Ions Uptake by Chitin-Based Shrimp Wasted Shells

Departamento de Engenhari a de Minas-Laboratorio de Technologia Minerale Ambiental-Universidade Federal do Rio Grande do Sul, Av. Osvaldo Aranha 99/512,. 